\title{
Determinants of Zakah Disclosure Level: Evidence for Indonesia
}

\author{
Siti Afidatul Khotijah*, Hadri Kusuma*
}

\author{
Received: 11.06 .2019 \\ Accepted: 27.11.2019 \\ DOI: $10.25272 /$ ijisef.583662 \\ Type: Research Article
}

\begin{abstract}
Accounting standard regulates the critical points of zakah disclosure in Islamic banking, but the voluntary disclosure has not been conducted by Islamic Banks. The determinants of zakah disclosure level for those banks are important to consider because zakah management in Indonesia has not been conducted optimally. Unfortunately, previous studies have not investigated the issue. This study has two objectives: to evaluate zakah disclosure level in Islamic Banks in Indonesia and to analyze the determinants of zakah disclosure level. This study measured the Shariah Supervisory Board using Islamic Governance (IG)-Score and the proportion of the Investment Account Holder (IAH) funds. The model then was controlled by the variables of bank size and leverage. The IG-score was measured using five indicators: the existence of SSB, the number of SSB members, cross-memberships, doctoral qualification of SSB members, and reputable scholars on SSB. The population was all public Islamic Banks in Indonesia, and the samples were collected using purposive sampling from the annual reports of the banks in the period of 2012-2016. Regression analysis and t-test were conducted to test the hypotheses and zakah disclosure level before and after revised PSAK 101 in 2014.

The result of this study indicated that the zakah disclosure level of the Islamic banks was quite high with an average of $67 \%$. Most of the disclosures were still limited to the existing rules required (mandatory disclosures). The t-test result indicated that zakah disclosure levels of 2014 and 2015 (implementation of revised PSAK 101 in 2014) were significantly different. As an interesting point, both Shariah Supervisory Board and the proportion of Investment Account Holder (IAH) funds significantly improved zakah disclosure level.
\end{abstract}

Keywords: Zakah, Disclosure, Shariah Supervisory, Investment Account

Jel Codes: M41, M48, Z12

\footnotetext{
* Graduate School of Accounting, Islamic University of Indonesia, khotijahafi@gmail.com, ORCID: https://orcid.org/0000-0003-4589-1137

** Islamic University of Indonesia, 883120104@uii.ac.id, ORCID: https://orcid.org/0000-0002-0224-686X
} 


\section{Introduction}

Zakah (Islamic tax) is an obligation for all Muslims as commanded by Allah SWT (God) in the 5 Pillars of Islam. The obligation to pay zakah is written in Al-Qur'an surah Al-Baqarah: 243. It comes as the third pillar of Islam, after Shahadat and Shalat (Prayer), indicating its importance for Muslims. Zakah also covers many aspects of human life. It has the potential to contribute to social security and harmony; bridging the gap between the rich and the poor and increasing individual purchases to boost national economy. In addition, as one of the sources of socio-economic development, Doktoralina and Bahari (2017) argued that zakah supported economic activities of a country, promoted social security, and an important source of revenue besides conventional taxes.

Zakah must be managed efficiently and reported accordingly. In Indonesia, zakah management is regulated formally under the Law of the Republic of Indonesia Number 23 of 2011 concerning zakah Management and emphasized by Government Regulation Number 14 of 2014 as the explanatory of Law Number 23 of 2011. In addition, based on Constitutional Court Decision Number 86/PUU-X/2012 October 31, 2013 concerning the legal test of Law Number 23 of 2011 concerning Zakah Management, general society can establish Amil Zakah institution with certain requirements. Furthermore, Shariah banking as a well-developed Shariah institution in Indonesia is responsible for managing zakah and reporting it as regulated under accounting principles.

From the perspective of accounting, Zakah has been regulated under the Statement of Financial Accounting Standards called PSAK109. It applies to all parties involved in zakah collections and distributions. However, the regulation does not apply to Shariah entities that collect and distribute zakah, infak, and/or sedekah that are not as the main operation, including Shariah banks. These Islamic banks must refer to accounting standards (PSAK 101) concerning Shariah Financial Report Presentation (Ikatan Akuntan Indonesia, 2011). In addition, financial statement disclosure is also regulated by Bank of Indonesia. Its regulation is No.14/14/PBI/2012 concerning Bank Report Transparency and Publication, and states that Shariah banks are responsible for reporting zakah management.

Any zakah disclosure by a shariah bank that does not conform to PSAK 101 is considered voluntary disclosure. The measurement index of this voluntary zakah disclosure has been developed by Samad and Said (2016). Similar to Corporate Social Responsibility disclosure or Islamic Social Reporting (ISR) in general, factors influencing zakah's disclosure need to be identified because zakah management and voluntary disclosure in Indonesia have not been optimally conducted. This study analyzes the development of zakah disclosure level in relation to revised PSAK 101. The study also investigates the determinants influencing voluntary zakah disclosure. This study combined factors influencing Corporate Social Responsibility (CSR) and Islamic Social Reporting (ISR) from Farook, et.al. (2014) with the focus on zakah disclosure from Samad and Said (2016) as an independent variable. The main variables included in this study were shariah supervisory board (SSB), proportion of 
Investment Account Holders (IAH) funds, with the company size as well as leverage as control variables. This study contributes to research regarding factors influencing zakah disclosure level in Indonesian shariah banking because the study on it is rarely. To the best author knowledge, there were no previous works investigating zakah disclosure level in Indonesia.

This paper begins with the background of the study. It is followed by the literature review relevant to this study as well as the development of the hypothesis. The next step presents the research method, and provides and discusses the result of hypothesis tests. Finally, it concludes with summary, implication and recommendation for further works.

\section{Theoretical Review and Hypothesis Development}

The stakeholder theory explains that a company is not an entity operating for its own interest but also the interests of its stakeholders. Information regarding company activities must be reported to all stakeholders for the sake of the decision-making process. Stakeholders can choose whether the information is useful or not for the company (Deegan, 2002). In addition, the legitimacy theory argues that an organization always strives to ensure that its operation is in accordance with social values and norms. In adopting the perspective of the legitimacy theory, a company voluntarily reports its activities that the management considers necessary to be disclosed to the surrounding community (Deegan, 2002). Therefore, it is an obligation of companies to disclose information to fulfill stakeholders' interests or conform to social norms.

\subsection{The Development of PSAK 101}

Conceptually, disclosure is an integral part of financial reports. However, company responsibility also involved voluntary disclosure such as Corporate Social Responsibility (CSR) or Islamic Social Reporting (ISR). Different from CSR, ISR does not only involve environment, minority interests, and employee but also issues related to social prosperity, interest in trading, and unfair trading (Othman, et.al., 2009) including Zakah.

Statement of Indonesian Financial Accounting Standards called PSAK 101 concerns shariah financial report presentation. It was issued by the Board of Financial Accounting Standards of the Institute of Indonesia Chartered Accountants on June 27, 2007. PSAK 101 replaced PSAK 59 concerning Shariah Banking Accounting issued on May 1, 2002. In relation to zakah's disclosure, this standard particularly explains zakah's disclosure by shariah banking in paragraphs 70-74. Based on the letter of National Council (Dewan Pengurus Nasional, DPN) of the Institute of Indonesia Chartered Accountants No. 0823-B/DPN/IAI/XI/2013, the authority of all shariah accounting products previously issued by the Board of Financial Accounting Standards is transferred to the Board of Shariah Accounting Standards. After being issued in early 2007, PSAK 101 was amended several times: a.) December 16, 2011 concerning revision of PSAK 1 on financial report presentation; b.) October 15, 2014 concerning revision of PSAK 1 on other comprehensive profit and loss presentation; and c.) May 25, 2016 concerning shariah insurance financial reports presented in Appendix B effective since January 1, 2017. New standard development in an institution will have both direct and indirect impacts on the level of disclosures not only because of awareness but also coercion, forcing the shariah institutions 
to comply with the new standard. Regarding zakah disclosure, the hypothesis was formulated as follow:

H1. The development of PSAK 101 improves the zakah disclosure level of shariah banking.

\subsection{Shariah Supervisory Board (SSB)}

As an effort to enhance zakah's disclosure in shariah banking, according to Bank of Indonesia regulations, Shariah Supervisory Board (SSB) supervises the implementation of shariah principles in banking. Following the stakeholder theory, information regarding company activities including zakah distribution and collection must be reported to all stakeholders for the sake of decision-making process (Deegan, 2002), and it also applies to all stakeholders of shariah banking. SSB is expected to ensure the implementation of Islamic laws and principles in shariah banks. With that responsibility, SSB may have a role in encouraging ISR activities and disclosure. There are several factors that may be influencing the effectiveness of SSB in performing its duty, namely size, independence, education and experience, board of directors, and disclosed information (Farook, et.al., 2011). Farook et al. (2011) using Islamic Governance (IG) score also found that SSB influenced CSR disclosure. A similar result was found by Rahman and Bukair (2013) using SSB characteristics. Charles and Chariri (2012) reported that SSB influenced ISR disclosure, and thus the hypothesis was formulated as follow:

H2. SSB (IG-score) has a positive influence on the zakah disclosure level of shariah banking.

\subsection{The Proportion of Investment Account Holders (IAH) Funds}

Customers are the main source of revenue that should be considered. Islamic banking recognizes Investment Account Holders (IAH) as mudharabah, an agreement between two parties in which one party provide fund or capital for business and another responsible for managing the business. A company should serve all stakeholders, including IAH. Following legitimacy theory, a company strives to ensure that it follows social values and norms and voluntarily reports its activities if expected by society. In Islamic norms, zakah is an obligation, and thus its disclosure becomes important among Islamic society, including IAH.

Muslim investors tend to invest their funds as IAH instead of being shareholders because they are interested in services offered by shariah banks and not shareholding. In addition, the IAH investment account can be accessed more easily than shares. IAH has no formal voting rights, but they influence supervision level "representatively" through shareholders (Farook, et.al., 2011). It is because shareholders' profit is determined by profit gained through the utilization of IAH funds, and thus the bigger IAH funds proportion, the more disclosures are conducted in shariah banking. A previous study conducted by Farook et. al. (2011) reported that the proportion of IAH funds significantly influenced CSR disclosure, and thus the hypothesis was formulated as follow:

H3. The proportion of Investment Account Holders (IAH) funds has a positive influence on the zakah disclosure level in shariah banking. 


\section{Research Method}

This study was conducted empirically to test the hypotheses of the influence of the dependent variables on the independent one. The target of research population was shariah banks in Indonesia. The samples were selected using purposive sampling with the criteria of publishing their annual reports on their websites and presenting the reports that end in December. From 13 shariah banks for the period of 2013-2016, there were 12 shariah public banks meeting the criteria, and thus there were 60 firm-year observations included in the study.

The study included the variables of the zakah disclosure level, SSB, proportion of IAH funds, and bank size and leverage as the control variables. The definitions and measurements of these variables are as follow:

1. Shariah Supervisory Board (X1) in this study referred to a board assigned in a shariah bank with its own characteristics and measured using Islamic Governance (IG) score. The score included the existence of SSB, the number of SSB Members, cross-memberships, doctoral qualification of SSB members and reputable scholars on SSB. The IG score was calculated by counting the scores of all items above with either 1 or 0 for each item according to the criteria.

2. The proportion of IAH funds (X2) in this study was investment funds in Shariah banks through mudharabah agreement, including mutlaqah and mudharabah muqayyadah. This variable was measured using the ratio between mudharabah investment funds and total assets, resulting in the ratio of proportion of IAH funds.

3. Company size (X3) in this study referred to the total asset in a company. It was measured using natural logarithm of total assets as implemented by Farook et al. (2011) and Widayuni and Harto (2014).

4. Leverage (X4) in this study was the ability of a company to fulfill its financial responsibility either in the short or long term if it was liquidated. It was measured using Debt Equity Ratio (DER), a ratio between total liability and total equity.

5. Zakah disclosure (Y) in this study referred to the study conducted by Samad and Said (2016) that was developed from Haniffa and Hudaib (2006) regarding the disclosure index. Thus, there were 15 measurement items for companies with zakah disclosure and 2 items for companies without zakah disclosure.

To achieve the first goal of this paper, a T-test was conducted to analyze the difference in zakah disclosure level before and after the revision of PSAK 101. This study also implemented regression equation to analyze the influence of the dependent variables on the independent variable. Classical assumption tests were conducted before concluding the results of hypothesis tests. Equation 1 was the regression equation to infer hypothesis 2 and 3 :

$\mathrm{Y}=\alpha+\beta 1 \mathrm{X} 1+\beta 2 \mathrm{X} 2+\beta 3 \mathrm{X} 3+\beta 4 \mathrm{X} 4+\mathrm{e}$ 


\section{Results and Discussions}

Table 1 presents descriptive data. The table indicates mean, median, maximum, minimum, standard deviation, skewness, and kurtosis for each variable in the study.

Table 1. Descriptive Statistics Result

\begin{tabular}{|l|c|c|c|c|c|}
\hline & $\mathrm{Y}$ & $\mathrm{X} 1$ & $\mathrm{X} 2$ & $\mathrm{X} 3$ & $\mathrm{X} 4$ \\
\hline Mean & 0.674444 & 4.250000 & 0.634129 & 22.85086 & 2.108831 \\
\hline Median & 0.733333 & 4.000000 & 0.705688 & 22.67360 & 1.611497 \\
\hline Maximum & 0.933333 & 5.000000 & 0.812808 & 25.09058 & 8.328047 \\
\hline Minimum & 0.066667 & 3.000000 & 0.038663 & 20.66083 & 0.365025 \\
\hline Std. Dev. & 0.206155 & 0.600141 & 0.210671 & 1.248548 & 1.967952 \\
\hline Skewness & -1.459254 & -0.148265 & -1.897468 & 0.174542 & 1.810349 \\
\hline Kurtosis & 4.656140 & 2.480969 & 5.354574 & 1.980175 & 5.726630 \\
\hline
\end{tabular}

The first hypothesis is that the development of new PSAK 101 improves the zakah disclosure level of shariah banking. This study examined the level of zakah disclosure before and after implementation of PSAK 101. As shown in Table 2 , $t$-test is significant at $5 \%$ level $(0.032<0.05)$ and therefore this study supports the hypothesis. There was a significant increase disclosure level in the financial reports in 2014.

Table 2. T-Test Comparison

\begin{tabular}{|c|c|c|c|}
\hline Mean & Std. Deviation & $\mathrm{t}$-value & $\mathrm{p}$-value \\
\hline-.05000 & .07035 & -2.462 & .032 \\
\hline
\end{tabular}

The zakah disclosure level increased from 0.6778 in 2014 to 0.7278 in 2015. In other words, the implementation of a change in regulation could change the level of zakah disclosure and enhance shariah banks to disclosure more items. This measurement of disclosure level was adopted from Samad and Said (2016) without any alteration. Thus, when it was aligned with Indonesian accounting standards, there were many disclosure items that had been required to be disclosed. PSAK 101 revision was very influential to the disclosure level, considering that most disclosures were conducted as part of company responsibility.

Table 3 shows the result of the regression test for the zakah disclosure level (Y) with SSB (X1) and IAH fund proportion (X2) as the independent variables and bank size (X3) and leverage (X4) as the control variables. Shariah Supervisory board (X1) positively and significantly influenced zakah disclosure level at $5 \%$ level $(0.0313<0.05)$. The coefficient of $X 1$ has a positive value of 0.090098 . The proportion of IAH funds (X2) also had a positive and significant influence on zakah disclosure level. This variable was significant at $1 \%$ level $(0.0003<0.01)$ and had a positive coefficient value of 0.0563128 . 
Table 3. Regression Results

\begin{tabular}{|c|c|}
\hline Variable & $\begin{array}{c}\text { Coefficient } \\
\text { (Standard Error) }\end{array}$ \\
\hline C & -0.907929 \\
$(0.203628)^{*}$
\end{tabular}

SSB had a positive and significant influence on the zakah disclosure level at $5 \%$ rate. The coefficient value was 0.090098 with a positive mark indicating that an increase of 1 unit in SSB increased auditor opinion accuracy for 0.090098 unit with the assumption that other independent variables were constant. It means that the higher the SSB score, the higher the level of zakah disclosure in Indonesian shariah banking.

A previous study with SSB as the factor influencing CSR disclosure by Farook et.al. (2016) showed a significant result. According to Farook et.al. (2014), the existence of SSB in shariah banks can enhance supervision, and thus increasing the amount of CSR information being disclosed. Thus, more information regarding shariah principles will also be disclosed thanks to the existence of SSB. According to AAOIFI (2005), SSB is responsible for ensuring that all transactions are conducted in accordance with shariah principles independent from the board of directors, maintaining the religious aspect in decision-making. Thus, the existence of SSB and its characteristics influences the zakah disclosure level in shariah banking.

The stakeholder theory explains that a company is not an entity operating for its own interest but also the interests of its stakeholders. Stakeholders and the company influence one another, creating a social relationship in the forms of responsibility and accountability. SSB is part of stakeholders that contribute to the disclosure level. Disclosed information regarding zakah will be used by stakeholders in decision-making, including the National Shariah Board of Indonesian Ulama Council to evaluate SSB's performance. The better the criteria of SSB, the higher the zakah disclosure level. 
In conclusion, the first hypothesis was valid and supported by the data. The zero hypothesis was rejected, meaning that SSB represented in IG score had a positive and significant influence zakah disclosure level.

\subsection{The Influence of the Proportion of Investment Account Holders (IAH) Funds on Zakah Disclosure Level}

The proportion of IAH funds had a positive and significant influence on zakah disclosure level at $5 \%$ rate. The coefficient value was 0.563128 with a positive mark indicating that an increase of 1 unit in the variable increased auditor opinion accuracy for 0.563128 unit with the assumption that other independent variables were constant.

This finding is in line with Farook et.al. (2011), who found that the same variable had a significant influence on CSR disclosure. In shariah banking, investment does not only mean buying shares but also investing through mudharabah agreement especially by Muslim customers, a striking difference between conventional and shariah banking. The profit and easy supervision access attract more customers to make an investment through mudharabah.

The stakeholder theory assumes that the existence of a company requires stakeholder support, and thus the company activities require the stakeholders' approval. The theory also states that the company must be able to adapt to the stakeholders with more power. As part of stakeholders, customers have the right to gain information regarding a bank for decisionmaking. Bigger proportion of temporary shirkah funds in a shariah bank indicates a bigger role of customers, and thus the bank must be able to disclose more information regarding zakah.

The legitimacy theory explains that a company always strives to ensure that its operation is in accordance with social values and norms, and the company voluntarily reports activities that the management considers necessary to be disclosed to the surrounding community. In an Islamic environment, zakah is an obligation, and its collection is an important matter. In addition, with shariah principles underlying shariah banks, they will voluntarily disclose zakah.

In conclusion, the second hypothesis was valid and supported by the data. It means that the zero hypotheses were rejected and thus the proportion of IAH funds had a positive and significant influence on zakah disclosure level.

\section{Conclusion}

This study mainly examined factors influencing the accuracy of the zakah disclosure level in Indonesian shariah banking. The findings indicated that SSB and the proportion of IAH funds had a positive and significant influence on zakah disclosure level. In addition, the t-test result showed that there was a significant improvement in the level of zakah disclosure after the revision of PSAK 101 in 2014 concerning Shariah Financial Report Presentation. 
The results may suggest some implications. First, that shariah banks need to improve these factors to boost their quality, particularly the proportion of IAH funds by attracting more investors with mudharabah agreement. To do so, shariah banks can create new products based on mudharabah in accordance with shariah principles. Larger amount of mudharabah funds increases shirkah funds and decreases the proportion of bank responsibility. Second, the finding of this study can be a point of consideration for the Institute of Indonesian Chartered Accountants (IAI) in arranging PSAK 101. The IAI organization may include the existence and characteristics of SSB as a requirement of zakah disclosure. In addition, the proportion of IAH funds can be included as a requirement for an entity to disclose more zakah-related information as a consequence of the increasing responsibility to its stakeholders. Third, the Indonesian Ulama Council as an institution under which SSB operates can evaluate SSB members that are going to be assigned in a particular shariah institution, and enhance their characteristics in terms of education, experiences, and positions. By doing so, SSB members can perform their duty better in supervising zakah management and thus increase voluntary zakah disclosure besides the obligatory one. Fourth, stakeholders can assess shariah banking performance based on several factors before making investment. They need to make investment in a bank with good SSB and larger proportion of IAH funds that indicate considerable zakah disclosure level, which can also attract potential customers to save their money in that bank. Lastly, the government, represented by BAZNAS as the institution that manages zakah nationally, may refer to this study as a consideration in assessing the level of zakah disclosure of a certain shariah bank and entrust the management of zakah to that bank. The bank can give more contributions to zakah management.

This study may be extended as follows. This study was conducted in a limited time from 2012 to 2016, and the result was different as time went by. This study also only involved shariah public banks in Indonesia. Future studies are expected to include not only shariah public banks but also shariah business units and Shariah Rural banks conducting zakah disclosures in Indonesia. In addition, other variables that may influence zakah's disclosure level such as age, ownership, performance, and other unexamined factors, need to be investigated. 


\section{References}

Akin, A., and Yilmaz, İ. (2016). Drivers of Corporate Social Responsibility Disclosures: Evidence from Turkish Banking Sector. Procedia Economics and Finance 38.

Andrikopoulos, A., Samitas, A., and Bekiaris, M. (2014). Corporate Social Responsibility Reporting in financial Institutions: Evidence from Euronext. Research in International Business and Finance.

Anggraini, F. R. (2006). Pengungkapan Informasi Sosial dan Faktor-Faktor yang Mempengaruhi Pengungkapan Informasi Sosial dalam Laporan Keuangan Tahunan. Simposium Nasional Akuntansi 9 Padang.

Chakroun, R., Matoussi, H., and Mbirki, S. (2017). Determinants of CSR disclosure of Tunisian listed banks: a multi support analysis. Social Responsibility Journal.

Charles, and Chariri. (2012). Analisis Pengaruh Islamic Corporate Governance terhadap Pengungkapan Islamic Social Responsibility. Diponegoro Journal of Accounting.

Cuganesan, S., Ward, L., and Guthrie, J. (2009). Legitimacy Theory: A Story of Reporting Social and Environmental Matters within the Australian Food and Beverage Industry. SSRN.

Deegan, C. (2002). The Legitimising Effect of Social and Enviromental Disclosures-a Theoretical Foundation. Accounting, Auditing and Accountability Journal.

Deegan, C., and Rankin, M. (1997). The Materiality of Environmental Information to Users of Annual Reports. Accounting, Auditing and Accountability Journal.

Drobetz, W., Merikas, A., Merika, A., and Tsionas, M. G. (2014). Corporate Social Responsibility Disclosure: The Case of International Shipping. Transportation Research Part E.

Esa, E., and Zahari, A. R. (2016). Corporate Social Responsibility: Ownership Structures, Board Characteristics and the Mediating Role of Board Compensation. Procedia Economics and Finance.

Farook, S., Hassan, M. K., and Lanis, R. (2011). Determinants of Corporate Social Responsibility Disclosure: The Case of Islamic Banks. Journal of Islamic Accounting and Business Research.

Ghozali, I. (2013). Aplikasi Analisis Multivariate dengan Program SPSS 21 Update PLS Regresi. Semarang: Universitas Diponegoro.

Giannarakis, G. (2014). The Determinants Influencing The Extent Of CSR Disclosure. International Journal of Law and Management.

Gubernur Bank Indonesia. (2004). Peraturan Bank Indonesia Nomor 6/24/PBI/2004. Jakarta: bank Indonesia. 
Habbash, M. (2016). Corporate Governance and Corporate Social Responsibility Disclosure: Evidence from Saudi Arabia. Social Responsibility Journal.

Hadi, S. (2007). Memanfaatkan Excel untuk Analisis Statistik. Yogyakarta: Ekonisia.

Haniffa, R., and Hudaib, M. (2007). Exploring the Ethical Identity of Islamic Banks via Communication in Annual Report. Journal of Business Ethics.

Harrison, J. S., and Wicks, A. C. (2013). Stakeholder Theory, Value, and Firm Performance. Business Ethics Quarterly.

Ikatan Akuntan Indonesia. (2011). Pernyataan Standar Akuntansi Keuangan Nomor 109. Jakarta: IAI.

Ikatan Akuntan Indonesia. (2016). Pernyataan Standar Akuntansi Keuangan 101: Penyajian Laporan Keuangan Syariah. Jakarta: Ikatan Akuntan Indonesia.

Indrawaty, and Wardayati, S. M. (2015). Implementing Islamic Corporate Governance (ICG) and Islamic Social Reporting (ISR) in Islamic Financial Institution (IFI). Procedia - Social and Behavioral Sciences.

Kansal, M., Joshi, M., and Batra, G. S. (2014). Determinants of Corporate Social Responsibility Disclosures: Evidence from India. Advances in Accounting, incorporating Advances in International Accounting.

Kurniawati, I. (2011). Praktikum Pengolah Data Elektronik. Yogyakarta: Fakultas Ekonomi Universitas Ahmad Dahlan.

Lestari, P. (2013). Determinants of Islamic Social Reporting in Syariah Banks: Case of Indonesia. International Journal of Business and Management Invention.

Lestari, Y. A., and Nuzula, N. F. (2017). Analisis Pengaruh Financial Leverage dan Operating Leverage terhadap Profitabilitas Perusahaan. Jurnal Administrasi Bisnis.

Muttakin, M. B., and Khan, A. (2014). Determinants of Corporate Social Disclosure: Empirical evidence from Bangladesh. Advances in Accounting, incorporating Advances in International Accounting.

Othman, R., Thani, A. M., and Ghani, E. K. (2009). Determinants of Islamic Social Reporting Among Top Shariah-Approved Companies in Bursa Malaysia. Research Journal of International Studies.

Perwataatmadja, K. A. (1992). Apa Dan Bagaimana Bank Islam. Yogyakarta: Dana Bhakti Wakaf.

Rahman, A. A., and Bukair, A. A. (2013). The Influence of the Shariah Supervision Board on Corporate Social Responsibility Disclosure by Islamic Banks of Gulf Co-Operation Council Countries. Asian Journal of Business and Accounting.

Saad, R. A., and Haniffa, R. (2014). Determinants of Zakah (Islamic tax) Compliance Behavior. Journal of Islamic Accounting and Business Research. 
Sakinah. (2014). Investasi dalam Islam. Iqtishadia.

Samad, K. A., and Said, R. (2016). Zakah Disclosure by Islamic Malaysian Bank. International Business Management.

Seftianne. (2011). Faktor-Faktor yang Mempengaruhi Struktur Modal pada Perusahaan Publik Sektor Manufaktur. Jurnal Bisnis dan Akuntansi.

Sunarsih, U., and Ferdiyansyah. (2017). Determinants of The Islamic Social Reporting Disclosure. Al-Iqtishad: Jurnal Ilmu Ekonomi Syariah.

Suwardjono. (2014). Teori AKuntansi: Perekayasaan Pelaporan Keuangan (Edisi ke-8). Yogyakarta: BPFE-Yogyakarta.

Wahab, N. A., and Rahman, A. R. (2013). Determinants of Efficiency of Zakah Institutions in Malaysia: A Non-parametric Approach. Asian Journal of Business and Accounting 6.

Widayuni, N., and Harto, P. (2014). Faktor-Faktor yang Mempengaruhi Corporate Social Responsibility pada Perbankan Syariah di Indonesia dan Malaysia. Diponegoro Journal of Accounting.

Widiastuti, H. (2004). Pengaruh Luas Ungkapan Sukarela dalam Laporan Tahunan terhadap Earnings Response Coefficient (ERC). Jurnal Akuntansi dan Investasi.

Yunus, M. (2016). Analisis Pengaruh Kepercayaan, Religiusitas dan Kontribusi Terhadap Minat Pedagang Mengeluarkan Zakah Di Baitul Mal. At-Tawassuth. 